\title{
Membangkitkan Kembali Tari "Melemang” yang Tenggelam Masa
}

\section{and THEATREREVIEW}

jurnal tari, teater, dan wayang volume 3 number 1, May 2020 page $36-45$

\author{
Doni Febri Hendra ${ }^{1}$ dan Nur Sekreningsih Marsan \\ Prodi Seni Tari, Universitas Universal Batam
}

\begin{abstract}
Reviving the Drowning Period of Melemang Dance. Melemang dance is a traditional art form. In ancient times, this dance was functioned for ceremonies in the kingdom and as a means of legalizing and celebrating the king's existence. The performance may only be done within the palace. This dance has not been performed for a long time due to the lack of guidance from the supporting community. This research uses descriptive and analytical methods to present data objectively based on facts or phenomena as they are. Furthermore, the facts and phenomena are analyzed according to the context of the discussion. Therefore, the research objective, namely the revitalization of the Melemang dance, can be achieved.
\end{abstract}

Keywords: melemang dance; drowning period; revitalization

\section{Pendahuluan}

Seni tari hadir dan berkembang karena ada masyarakat pendukungnya. Tanpanya, tari tidak bertahan hidup. Selain itu, tari merupakan salah satu cabang seni penyangga kebudayaan. Dalam hal ini, Umar Kayam (1981: 39) menjelaskan bahwa kesenian tidak pernah lepas dari masyarakat sebagai salah satu unsur terpenting dari kebudayaan itu sendiri. Sehubungan dengan hal tersebut, tari Melemang merupakan salah satu bentuk kesenian tradisional dari Desa Penaga, Kecamatan Teluk Bintan, Kepulauan Riau, yang menjadi salah satu unsur kebudayaan hidup. Tari itu berkembang di tengah-tengah masyarakat pendukungnya. Pada masa dahulu tari ini difungsikan untuk upacara-upacara kerajaan dan sebagai bagian dari penobatan raja di tengah masyarakatnya. Selain itu, tari ini juga selalu ditampilkan ketika ada tamu kerajaan yang sedang berkunjung. Tempat pertunjukaannya pada saat itu hanya boleh dilakukan di dalam istana. Tujuan ditampilkan tarian tersebut di lingkup istana dimaknai bahwa raja memiliki suguhan yang menarik, baik untuk dirinya sendiri, untuk menghibur tamu kerajaan yang datang, maupun juga bertujuan untuk mengajarkan penonton menjadi lebih tertib dan khidmat saat menyaksikannya.

Namun demikian, tari Melemang sekarang tidak lagi berfungsi sebagaimana dahulunya. Bahkan tari ini sudah lama tidak ditampilkan di tengah-tengah masyarakat. Dengan demikian, keberadaan tari Melemang kurang mendapat pembinaan dari masyarakat pendukungnya. Di Desa Penaga, hampir tidak ada lagi anak muda yang mempelajari tari Melemang, kecuali pewaris-pewaris tradisi yang sudah tua usianya. Keadaan tersebut dikhawatirkan akan menyebabkan tari tradisional ini berangsur hilang dari peredaran masa, karena kesenian modern dianggap lebih menarik untuk dinikmati oleh anak-anak muda. Kesenian modern, seperti organ tunggal; hiburan virtual yang selalu menyuguhkan hiburan yang menarik; berbagai jenis musik seperti pop, rock, dangdut; dan terutama drama Korea; membuat generasi muda lebur ke dalam pertunjukan tersebut. Bahkan kaum tua

\footnotetext{
$1 \quad$ Alamat korespondensi: Prodi Seni Tari Universitas Universal Batam. Komplek Maha Vihara Duta Maitreya Bukit Beruntung, Sungai Panas, Batam 29433. Email: dhonkbara@gmail.com; HP.: 08126739514.
} 
pun sekarang menyukai pertunjukan dengan penyajian yang menarik. Dengan demikian, sudah menjadi tugas lembaga kesenian yang ada di Kepulauan Riau untuk melestarikan kesenian tradisional agar tidak tersingkirkan oleh kesenian modern saat ini yang lebih diminati oleh berbagai lapisan masyarakat. Universitas Universal Batam, suatu lembaga yang peduli terhadap pendokumentasian seni-seni tradisi terutama tari-tari tradisi Melayu, mencoba melakukan revitalisasi tari Melemang yang dianggap sudah punah, tetapi pewarisnya masih tersisa. Dalam hal ini revitalisasi dilakukan \pm 8 bulan dengan proses awal survey ke Desa Penaga. Berdasarkan fenomena revitalisasi yang dilakukan terhadap tari Melemang, permasalahan kebertahanan tarian tersebut menjadi perhatian utama.

Permasalahan kebertahanan tari $\mathrm{Me}$ lemang memunculkan pertanyaan mengenai keberlangsungan tari tersebut dan bentuk koreografi tari Melemang itu sendiri setelah mengalami revitalisasi. Kedua permasalahan di atas dibahas melalui pengamatan di lapangan dan melalui pengalaman penulis menarikan hasil revitalisasi tari Melemang tersebut. Tujuan penelitian ini adalah mengkaji keberlangsungan tari Melemang di Desa Penaga dengan bentuk koreografi aslinya dan bentuk koreografi tari Melemang itu sendiri setelah mengalami revitalisasi. Selain itu, tulisan ini diharapkan dapat digunakan untuk proses sosialisasi di tengah masyarakat Penaga agar tari Melemang kembali berkembang pada kelompok kesenian yang ada di daerah tersebut.
Dalam kajian mengenai tari Melemang ini perlu ditinjau beberapa tulisan dan hasil penelitian agar tidak terjadi tumpang tindih terhadap objek kajian lainnya. Sejauh ini belum ditemukan bahasan mengenai hasil revitalisasi tari Melemang itu sendiri untuk dijadikan bahan penulisan. Namun demikian, ditemukan laporan penelitian tentang tari Melemang, di antaranya: laporan penelitian Haliz Zefri berjudul "Tari Melemang Bentan Penaga" sebuah penelitian yang menjelaskan analisis dan fungsi tari serta struktur koreografi dan rias busana. Hasil penelitian tersebut memiliki kesamaan cerita tarian, tetapi bentuk kajiannya berbeda. Namun demikian, hal tersebut dapat dijadikan bahan perbandingan dalam kajian tari Melemang yang hilang keberadaannya di tengah masyarakat di pulau Bintan Penaga. Oleh sebab itu, diperlukan konsepkonsep pemikiran dari beberapa ahli yang berhubungan dengan permasalahan tersebut.

Untuk membahas masalah koreografi yang berhubungan dengan bentuk, konsep Lois Ellfeldt (1977: 15) yang menyatakan bahwa bentuk adalah wujud rangkaian gerak atau peraturan laku-laku. Di sisi lain, Jacqueline Smith (1985: 6) juga mengatakan, bahwa bentuk adalah wujud, dan struktur sesuatu yang dapat dibedakan dari materi yang ditata. Selanjutnya, dalam Kamus Besar Bahasa Indonesia (1988: 103) didefinisikan kata bentuk sebagai rupa, wujud. Alma M. Hawkins dalam Y. Sumandiyo Hadi (1990) mengatakan bahwa gerak dalam tarian merupakan medium ekspresi dari gerak tubuh penari. Melalui

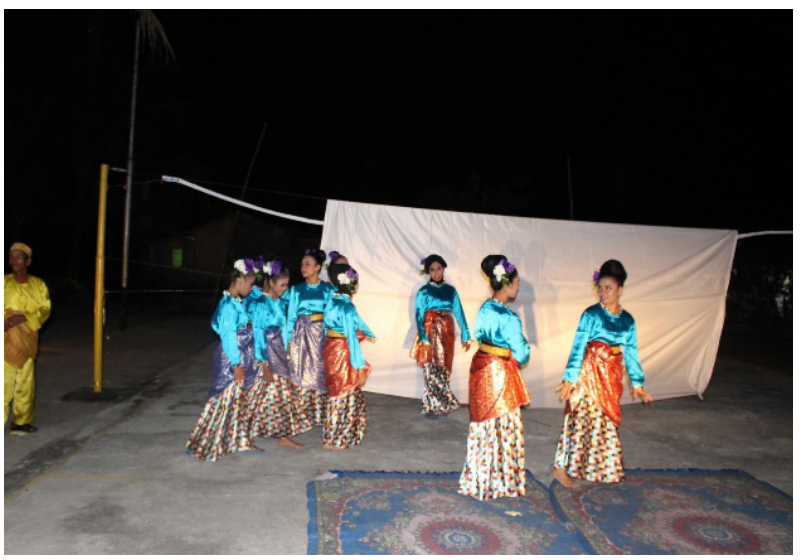

Gambar 1. Pertunjukan Tari Melemang sebelum direvitalisasi. (Sumber: Tim peneliti Doni Hendra, dkk.) 
bentuk tari, gerak dipahami dan dimengerti meskipun gerak tersebut berasal dari gerakgerak dasar manusia, tetapi makna simbolis dari gerak sebenarnya mencerminkan dari kehadirannya. Pada umumnya, gerak dalam tari Melemang ini adalah gerak-gerak Melayu dan sesuai dengan keadaan alam Melayu itu sendiri. Soedarsono (1977: 40) menjelaskan bahwa ada elemen-elemen komposisi tari yaitu gerak, pola lantai, desain dramatik, desain atas, komposisi kelompok, tema, musik dan perlengkapan. Teori ini dipakai untuk menata ulang tari Melemang yang dipelajari dari bentuk tradisi ke dalam bentuk baru yang digunakan untuk kebutuhan pembelajaran mahasiswa nantinya.

Untuk melihat fenomena perubahan masyarakat terhadap pertumbuhan tari tradisional, konsep Mursal Esten (1993: 117) dalam bukunya Minangkabau dan Perubahan menjelaskan bahwa perubahan dan perkembangan masyarakat terhadap tari Minangkabau berkaitan erat dengan perkembangan sosial budaya masyarakat pendukung suatu tari. Suatu bentuk kesenian akan lestari dalam masyarakat apabila kesenian tersebut dapat mengikuti perkembangan kesenian di masa depan. Seandainya kesenian itu tidak dapat menyesuaikan dengan perkembangan zaman, kesenian itu ditinggalkan oleh lingkungannya. Dengan kata lain, kesenian itu tidak lagi digemari oleh masyarakat pendukungnya (musnah), karena perubahan menjadi hal yang tidak dapat dielakkan dalam perkembangan bentuk kesenian. Di sisi lain, Sal Murgianto (2004: 11), dalam bukunya Tradisi dan Inovasi, mengatakan perubahan atau perkembangan biasanya hanya diprakasai oleh orangorang yang memiliki kekuasaan: kepala suku atau raja. Adapun khalayak ramai yang merupakan bagian terbesar masyarakat lebih suka memelihara tradisi dengan jalan membiarkannya dengan apa adanya. Hal ini sangat terkait dengan keberadaan tari Melemang dalam masyarakat Penaga yang membiarkan tari Melemang hampir punah.
Untuk mengkaji masalah revitalisasi kesenian tradisional, Tjetjep Rohendi Rohidi (2000:206) menjelaskan bahwa pembahasan revitalisasi dilakukan dengan menggunakan perspektif eko-budaya, yaitu sebuah pendekatan sistem dengan melihat masalah dan cara menganalisisnya sebagai suatu keseluruhan yang mencakup unsur-unsur yang saling berkaitan antarmanusia, nilai-nilai dan lingkungan. Yasraf Amir Piliang (2004) dengan buku Dunia Yang Dilipat Tamasya Melampaui Batas-Batas Kebudayaan melalui makalah Daryusti “Keberlangsungan Tari Tradisi", West Sumatra Dance Festival (2006) mengatakan revitalisasi berarti prinsip atau sistem-sistem lokal harus diperbaharui, disesuaikan dengan kondisi dan kebutuhan masyarakat, yang juga berarti sistem-sistem lokal yang harus diberi napas baru dilakukan secara sistematis dan terencana. Teori akan sangat mendukung pada pembahasan revitalisasi yang dilakukan oleh akademisi terhadap tari Melemang yang ada di Desa Penaga yang sudah hampir punah karena generasi berikutnya yang mulai meninggalkan kesenian tradisional tersebut.

Musik dalam suatu tarian sangat bertumpu pada gerak-gerak tari, seperti yang dikatakan oleh I Wayan Senen dalam Pengantar Musik Tari (1983: 12), bahwa musik pengiring tari adalah musik yang disajikan sedemikian rupa mengikuti ritme gerak tariannya, sehingga tari, dalam hal ini, dapat mendominasi musiknya. Teori ini dapat menentukan unsur-unsur musik pada tari $\mathrm{Me}$ lemang. Dalam melakukan penelitian tentang bentuk perubahan revitalisasi tari Melemang di desa Penaga, metode yang digunakan adalah deskriptif dan analisis, Metode ini bertujuan untuk memaparkan data secara objektif yang berdasarkan kepada fakta atau fenomena seperti kenyataannya, kemudian dicoba untuk menganalisisnya sesuai dengan konteks pembahasan agar tujuan penelitian dapat tercapai.

Adapun tahap-tahap yang dilakukan dalam penelitian ini adalah sebagai berikut. Penelitian ini diawali dengan dilakukannya studi kepustakaan guna memperoleh informa- 
si yang berkaitan dengan rumusan masalah. Informasi ini diawali dengan buku-buku tercetak maupun laporan dari hasil penelitian atau makalah seminar, dengan tujuan agar penelitian dapat dijaga keorisinilannya. Kegiatan pengumpulan data ini dilakukan, baik secara langsung maupun tidak langsung, guna menjawab seluruh pertanyaan yang telah dirumuskan, dengan cara-cara sebagai berikut.

a. Observasi

Observasi dilakukan untuk mengamati kondisi sosial masyarakat dan perkembangan kesenian di daerah tersebut dengan harapan diperoleh informasi yang dibutuhkan.

b. Wawancara

Wawancara dilakukan dengan informan yang telah ditetapkan, yang ditujukan kepada orang-orang yang mengetahui latar belakang tari Melemang. Wawancara dilakukan dengan menggunakan buku catatan, handy camera yang dilengkapi dengan recorder dengan tujuan untuk mengingat kembali data yang diperoleh dari hasil wawancara.

c. Dokumentasi

Untuk mendokumentasikan penelitian dapat digunakan beberapa alat bantu yang sangat berguna dalam pengumpulan data, di antaranya: handy camera dan foto camera.

Instrumen yang paling penting dalam penelitian ini adalah peneliti sendiri, di samping alat alat lainnya yang juga dibutuhkan. Oleh karena itu, peneliti harus benar benar memahami dan mendalami data yang diperoleh di lapangan.

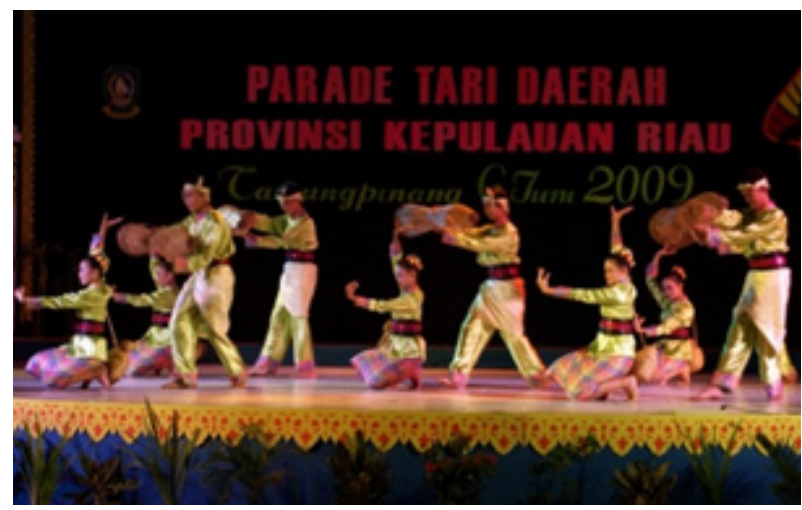

Setelah semua data terkumpul diolah dengan jalan mengklasifikasikan dan kemudian diseleksi. Data yang mendukung pokok permasalahan dikelompokkan menurut jenisnya. Pada tahap ini dilakukan penyerderhanaan data dalam bentuk yang lebih mudah dibaca dan diinterprestasikan.

\section{Keberlangsungan Tari Melemang}

Tari Melemang merupakan tarian tradisional yang berasal dari Tanjung Pisau Bintan Penaga, Kecamatan Bintan, Kepulauan Riau. Tarian ini ditampilkan pertama kali sekitar abad ke-12, ketika itu tari Melemang hanya dimainkan di istana kerajaan Melayu Bintan yang pusatnya berada di Bukit Batu Bintan. Pada masa itu, tari ini hanya dikenal di dalam istana saja karena ketika ditampilkan hanya untuk sebagai hiburan raja atau menghibur tamu kerajaan yang sedang berkunjung. Tari Melemang awalnya ditarikan oleh perempuan yang menjadi dayang-dayang istana berjumlah empat belas orang. Namun, sejak kerajaan Bentan mengalami keruntuhan, tari Melemang dipertunjukan untuk rakyat di luar istana sebagai pertunjukan hiburan rakyat. Saat ini, tari ini hanya sesekali waktu dipertunjukan dalam acara seremonial daerah setempat. Hal inipun akan dilakukan kalau pemain dari tari Melemang ada. Sekarang ini, pewaris yang masih ada yaitu Ibu Rokiah yang mengajarkan tari Melemang kepada siswi Sekolah Menengah Atas saja yang kebetulan penduduk Desa Tanjung Pisau Penaga itu sendiri.

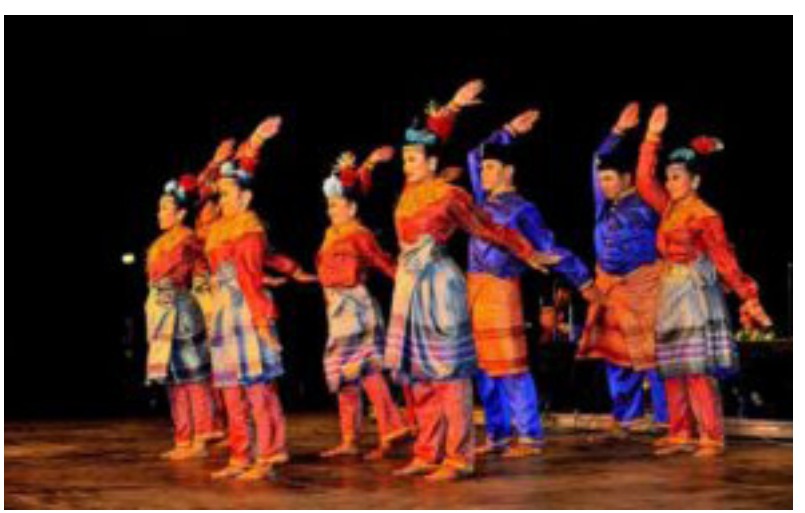

Gambar 2. Gerak Tari Melemang sebelum direvitalisasi. (Sumber: riau.go.id) 


\section{Pewaris Tari Melemang yang masih Tersisa}

Dalam melakukan suatu penelitian, hal yang merupakan cakupan pembahasan jenis data dan sumber data selalu terkait dengan empat hal. Keempat hal dimaksud, yakni: (1) keterkaitannya dengan fokus penelitian, (2) sifat analisis terhadap masalah yang menjadi fokus penelitian, (3) cara perolehan data, dan (4) sumber perolehan data. Dalam perolehan data tentang tari Melemang, Daryusti (2006: 47) juga mengatakan data dibedakan atas dua, yaitu: data primer dan sekunder, Data yang didapat secara lansung dari pewaris tari $\mathrm{Me}$ lemang disebut data primer. Selain itu, data primer juga diperoleh ketika mengikuti kegiatan tari Melemang yang dilakukan oleh Prodi Seni Tari, Universitas Universal Batam, dan juga melalui keterangan narasumber yang benar-benar mengetahui perihal tari $\mathrm{Me}$ lemang, yaitu bapak Edi Ismail, selaku pimpinan Sanggar Dang Merdu Tandak Lemang dan Ibu Rokiah selaku penari asal tari Melemang.

\section{Asal-usul Tari Melemang}

\section{Tari Melemang pada Masyarakat Penaga}

Asal usul tari Melemang di Desa Tanjung Pisau Penaga ini sampai sekarang belum dapat diketahui dengan pasti, waktu pertama kali tari itu muncul. Dari informasi yang diperoleh

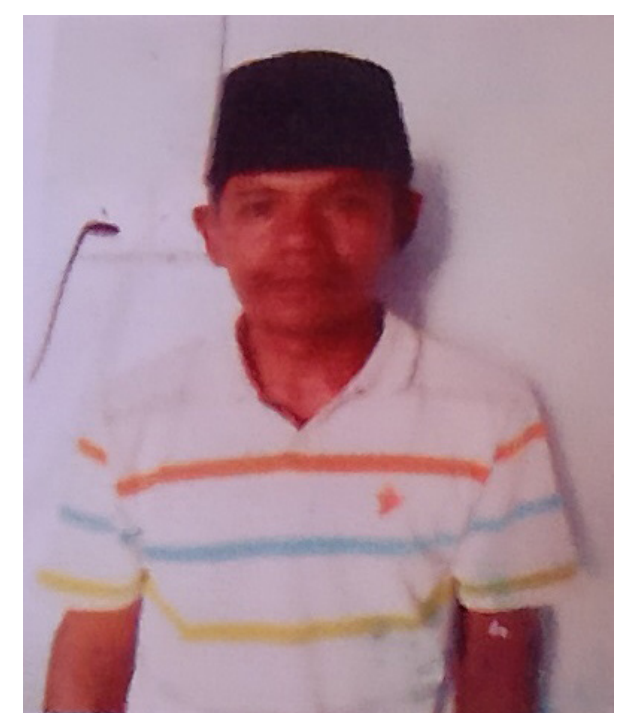

Gambar 3. Bapak Edi Ismail, pimpinan Sanggar Dang Merdu Tandak Lemang. (Sumber: Doni Febri Hendra) di lapangan, tari Melemang adalah kesenian yang hidup dari suatu kelompok masyarakat dan ditarikan oleh masyarakat itu sendiri.

Menurut informan yang sekaligus penari tari Melemang, yaitu Ibu Rokiah yang sudah tua usianya, tari Melemang ini ditarikan oleh empat belas orang penari putri. Dalam setiap pertunjukannya, para penari memperlihatkan kebolehannya dengan melakukan gerak kayang sambil mengambil sesuatu yang diletakkan di lantai, seperti sapu tangan, uang, dan benda lainnya. Tari Melemang diiringi oleh alat musik, seperti biola, gendang, rebana, gong, serta diiringi oleh vokal (dendang).

\section{Gerak Tari Melemang}

Gerak merupakan elemen paling mendasar dalam sebuah tarian yang lahir dari anggota penari. Seperti Alma M. Hawkins dalam Y. Sumandiyo Hadi (1990) menyatakan bahwa gerak dalam tarian sebagai medium ekspresi. Dari gerak tubuh penari akan terlihat bentuk tari dan gerak yang dapat dipahami dan dimengerti, meskipun gerak tersebut berasal dari gerak-gerak dasar manusia. Namun demikian, makna simbolis gerak sebenarnya mencerminkan kehadirannya.

Pada umumnya, gerakan yang dilakukan dalam tari ini adalah gerakan Melayu, dan sesuai dengan kondisi alam di Kepulauan Riau.

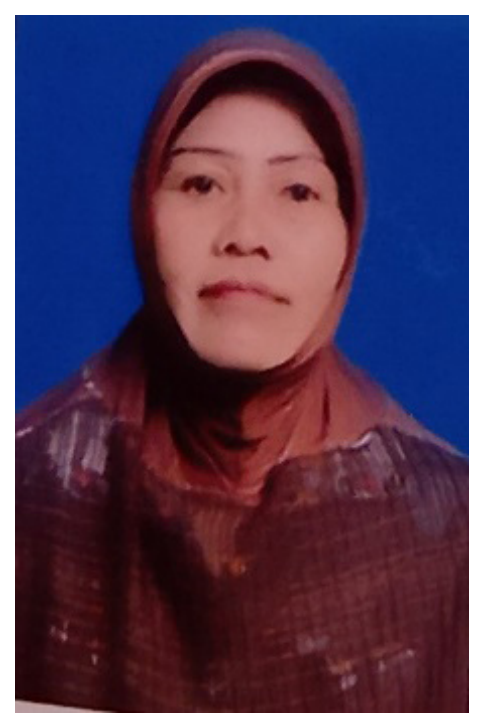

Gambar 4. Ibu Rokiah pewaris Tari Melemang. (Sumber: Doni Febri Hendra) 


\section{Koreografi Tari Melemang yang Hampir Punah}

Adapun gerak-gerak pokok tari Melemang adalah sebagai berikut:

1. Gerak Joget

2. Gerak Inang

3. Step

4. Gerak Zapin

5. Gerak Melemang

6. Gerak Melemang melantai

7. Gerak Melemang menggapai

8. Gerak Melemang menggigit

\section{Pola Lantai Tari Melemang}

Pola lantai adalah garis-garis yang dilalui penari di atas pentas. Garis-garis yang dilalui itu terdiri dari dua pola, yaitu: pola lantai lurus dan pola melengkung. Pola lantai yang digunakan dalam tari Melemang adalah pola lantai garis lurus sehingga kesan yang ditimbulkan sederhana tetapi kuat.

\section{Musik Iringan Tari Melemang}

Musik dan tari adalah satu kesatuan yang tidak dapat dipisahkan. Hal ini dikarenakan oleh musik dalam tari merupakan suatu perpaduan yang sangat harmonis. Oleh karena itu, tidak semua musik bisa mengiringi tari. Musik dalam suatu tari sangat bertumpu pada gerak-gerak tari. Seperti yang dikatakan oleh I Wayan Senen dalam Pengantar Musik Tari (1983: 12), bahwa musik pengiring tari adalah musik yang disajikan sedemikian rupa sehingga dapat mengikuti ritme gerak tariannya. Oleh karena itu, tari dalam hal ini dapat mendominasi musiknya. Selain bunyi dari alat musik yang dimainkan, tari Melemang ini juga diiringi oleh vokal.

\section{Rias dan Busana Tari Melemang}

Dalam suatu penyajian sebuah tarian, busana merupakan salah satu faktor pendukung yang sangat penting. Sehubungan de ngan hal itu, busana yang dipakai harus sesuai dengan jenis tariannya. Pada umumnya, busana tari selalu diatur menurut kebutuhan tari dan tidak mengganggu dalam bergerak. Dalam pertunjukan, terkadang kostum dapat menentukan berhasil atau tidaknya sebuah pertunjukan. Selain itu, busana juga menentukan karakter yang dibawakan oleh penari, dan dalam menata pakaian tentu saja sesuai dengan bentuk (tema) dan bentuk geraknya. Rias yang dipakai dalam pertunjukan tari $\mathrm{Me}$ lemang adalah rias cantik panggung. Sementara itu, busana tari Melemang adalah busana yang bernuansa Melayu yang menunjukkan kesopanan wanita Melayu.

\section{Revitalisasi Tari Melemang}

Daryusti (2006: 3-4) dalam makalahnya yang berjudul "Keberlangsungan Tari Tradisi" yang disajikan pada seminar internasional dengan tema Minangkabau Contemporery Dance Festival (WSDF) mengutip pendapat Piliang yang mengatakan bahwa revitalisasi berarti prinsip atau sistem-sistem lokal harus diperbaharui, disesuaikan dengan kondisi dan kebutuhan masyarakat. Dengan kata lain, revitalisasi berarti sistem-sistem lokal yang harus diberi nafas baru yang dilakukan secara sistematis dan terencana. Supaya proses kerja yang akan dilaksanakan untuk suatu revitalisasi tercapai perlu dilakukan langkah-langkah dalam merevitalisasi tari tradisi yaitu: (1) memahami proses dari kerja yang akan dilaksanakan; (2) menerapkan teknik-teknik yang harus dilakukan; dan (3) memiliki dasar untuk menghidupkan kembali tari tradisi. Seseorang yang ingin melakukan revitalisasi perlu memiliki dasar atau alasan dalam melaksanakan kegiatan tersebut. Dasar revitalisasi dapat berupa: (1) penari tari tersebut sudah tua dan tidak ingat lagi semua gerakan tari tradisi; (2) kebutuhan masyarakat terhadap tari tradisi; (3) memunculkan kekhususan daerah setempat terhadap tari tradisi; dan (4) agar tari tradisi tidak punah. Keempat poin tersebut juga menjadi dasar 
revitalisasi tari Melemang di Desa Tanjung Pisau, Kecamatan Bintan. Oleh karena itu, revitalisasi perlu dilakukan oleh masyarakat akademis Prodi Seni Tari, Universitas Universal Batam. Sebagai lembaga seni, masyarakat bertanggung jawab atas keberlansungan suatu kebudayaan, baik kebudayaan setempat maupun dari luar daerah.

\section{Revitalisasi Tari Melemang oleh Program Studi Tari di Universitas Universal Batam}

Abad ke-21 memperlihatkan semakin menyatunya berbagai kebudayaan dunia dengan segenap unsurnya yang saling terkait. Unsur-unsur tersebut bergantung antara satu dengan yang lainnya. Hal itu muncul akibat beroperasinya dua arus kekuatan, yaitu arus global dan lokal, arus modernitas dan tradisi, arus lama dan baru, arus masa kini dan masa lampau, arus yang berasal dari luar dan yang bersumber dari akar setempat, yang mengakibatkan ancaman bagi perkembangan budaya atau seni lokal secara umum, seperti tari Melemang yang pada masa dahulunya sebuah seni pertunjukan di kerajaan Melayu. Tari ini juga mengalami proses tarik menarik antara dua kekuatan arus, yang pada masa lalunya adalah sebuah kehidupan budaya dan seni pertunjukan yang menjadi satu aktivitas dalam lingkungan masyarakat (komunal). Namun saat ini, posisi budaya dan seni pertunjukan tari Melemang tidak dapat lagi dibandingkan dengan masa lalunya, khususnya di Desa Tanjung Pisau Penaga. Di tengah perubahan zaman, kehidupan budaya dan seni pertunjukan masyarakat Penaga mulai berkembang di luar sistem sosial yang telah menopang pertunjukannya selama ini, sehingga tari Melemang mulai tergeser.

Seperti diungkapkan Mursal Esten (993: 117) bahwa suatu bentuk kesenian akan dapat lestari dalam masyarakat jika kesenian tersebut dapat mengikuti perkembangan kesenian di masa depan. Jika kesenian tidak dapat menyesuaikan dengan perkembangan zaman, kesenian tersebut ditinggalkan oleh lingkungannya. Dengan kata lain, kesenian itu tidak lagi digemari oleh masyarakat pendukungnya (musnah) karena perubahan tidak dapat dielakkan dalam perkembangan bentuk keseniannya. Bapak Edi Ismail menyatakan sudah jarang sekali tari Melemang ini ditampilkan. Hal ini menunjukan bahwa Melemang tidak lagi digemari oleh masyarakat yang dahulu sebagai pendukungnya. Mereka lebih cendrung menikmati kesenian masa kini, seperti tari modern, budaya K-Pop, serta musik dangdut yang telah dikemas sesuai dengan perkembangan zaman sekarang.

Untuk itu, pembinaan terhadap kesenian daerah pada masa kini merupakan masalah yang perlu mendapat perhatian serius, baik dari pemerintah maupun masyarakat. Ilmu pengetahuan yang mengkaji masalah kesenian, kebudayaan umum, upaya pembinaan, pengembangan dan pelestarian kesenian, tidak akan dapat dilakukan secara sempurna apabila tidak dilandasi oleh kegiatan penelitian terhadap kesenian daerah tersebut. Pembinaan kebudayan dan pelestariannya dapat dilakukan oleh suatu lembaga kesenian yang ada di Kepulauan Riau, yaitu Universitas Universal Batam, terhadap kesenian tradisional yang ada di daerah tersebut. Untuk itu, permasalahan
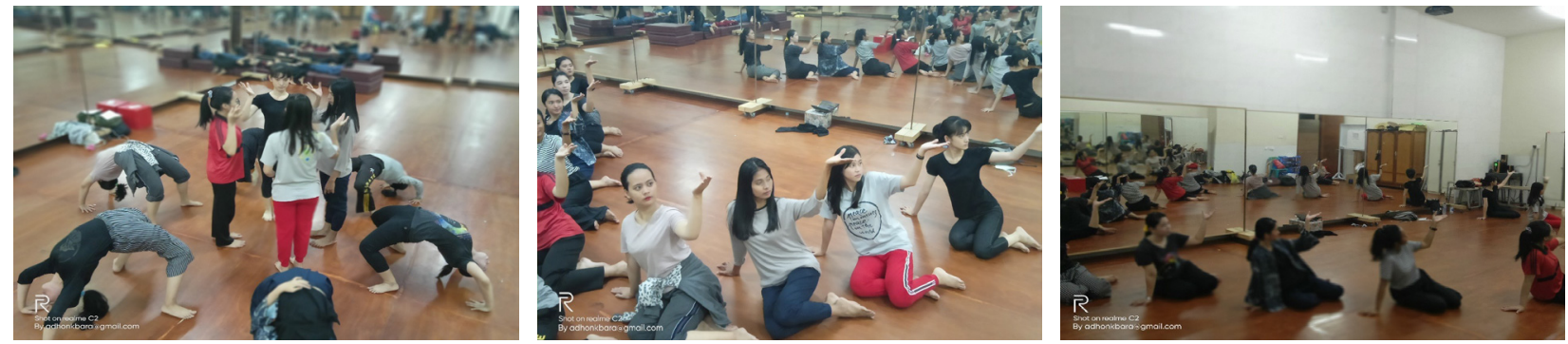

Gambar 5. Proses revitalisasi yang dilakukan oleh tim peneliti melalui mahasiswa Prodi Tari Universitas Universal Batam. (Sumber: Tim Peneliti Doni Hendra, dkk.) 
ini diangkat karena masyarakat datang ke sebuah pertunjukan untuk mencari hiburan yang dapat menambah apresiasi mereka. Untuk memenuhi tuntutan ini, tari tradisional harus siap bersaing. Materi seni pertunjukan harus didukung oleh berbagai aspek yang membuat penonton merasa kagun saat menonton. Oleh karena itu, harus dimasukan unsur pertunjukan modern dan prima tanpa menghilangkan bentuk ketradisionalannya, seperti dari pengolahan bentuk tari, kostum, dan pemilihan penari. Semua unsur tersebut menjadi keindahan suatu sajian seni tari ditambah kelengkapan pertunjukan dan artistik yang memanjakan mata penonton.

Untuk mengkaji masalah revitalisasi kesenian tradisional, perlu dipahami paparan yang dikemukakan Tjetjep Rohendi Rohidi pada Kesenian dan Pendekatan Kebudayaan (2000: 206), yaitu pembahasan dilakukan dengan menggunakan perspektif eko-budaya, yaitu sebuah pendekatan sistem dengan melihat masalah dan cara menganalisisnya sebagai suatu keseluruhan yang mencakup unsurunsur yang saling berkaitan antarmanusia, nilai-nilai, dan lingkungan.

Revitalisasi dilakukan selama \pm 8 bulan dengan proses awalnya survei lapangan oleh beberapa orang dosen tari dan mahasiswa. Pada bulan berikutnya, tim mulai belajar tari Melemang. Proses belajar tersebut dimulai dari gerak, makna gerak, dan musiknya. Ciri dari tari Melemang ini berupa melemang (gerak kayang). Setelah ragam gerak dikuasai, tim menyusun bentuk tari sesuai dengan unsurunsur pendukung tari dengan menggunakan semua elemen-elemen komposisi tari, seperti yang dijelaskan Soedarsono (1977: 40), bahwa ada sembilan elemen: komposisi tari, gerak, pola lantai, desain atas, desain dramatik, komposisi kelompok, tema, dan perlengkapan. Tim akan mengubah bentuk tari Melemang ke dalam bentuk baku agar bisa digunakan nantinya untuk lembaga, khususnya di Prodi Seni Tari. Tim menggunakan hitungan 1x8 untuk membatasi perubahan gerak.
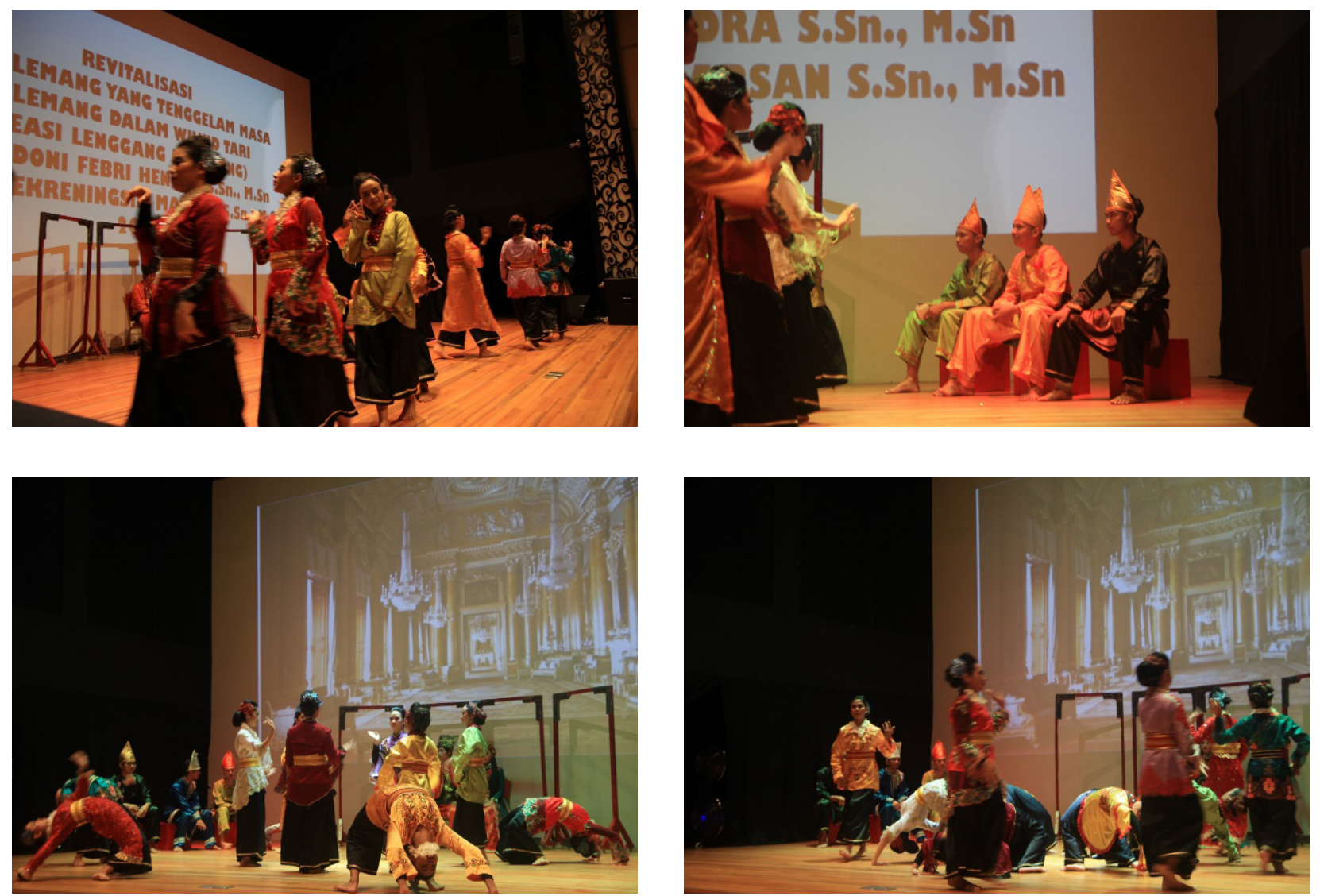

Gambar 6. Bentuk revitalisasi Tari Melemang oleh tim peneliti Universitas Universal Batam. (Sumber: Tim Peneliti Doni Hendra, dkk.) 
Revitalisasi yang dilakukan selama beberapa bulan sudah mencukupi sehingga hal yang ingin dicapai dalam melakukan revitalisasi tercapai, walau belum sempurna seperti yang diingankan. Kondisi tersebut disebabkan oleh jarak wilayah penelitian yang cukup jauh. Peneliti harus menyeberangi lautan sebelum selanjutnya melalui perjalanan darat yang cukup jauh. Namun, revitalisasi ini masih dapat terlaksana. Selain mengajarkan kembali tari Melemang kepada generasi muda, khususnya murid Sekolah Menengah Atas yang ada di Desa Penaga, tari Melemang juga diajarkan kepada mahasiswa Universitas Universal Batam. Proses pembelajaran dilakukan tanpa menghilangkan bentuk aslinya, sehingga bentuk koreografi tari Melemang masih tetap sama dengan aslinya. Letak perubahan yang dipelajari oleh tim revitalisasi terletak pada bentuk pola lantai dan penyempurnaan iringan musik. Revitalisasi tari Melemang menarik untuk dipertontonkan ke masyarakat umum dalam peristiwa budaya apapun, baik dipertunjukan dalam daerah maupun luar daerah, sesuai dengan kebutuhan dan perkembangan dunia tari saat ini. Selain dari pembaharuan yang dilakukan dalam bentuk gerak dan pola lantai, juga terdapat pembaharuan dalam bentuk kostum yang kekinian. Seperti halnya kostum tari Melayu untuk pertunjukan yang difungsikan untuk hiburan semata, bentuk kostum tari Melemang sedikit lebih mewah dan glamor tanpa meninggalkan kesan kostum tari Melayu untuk wanita Melayu.

\section{Penutup}

Pertunjukan tari Melemang di Pulau Bintan, tepatnya di Desa Penaga, Kepulauan Riau, tergolong pada jenis tari kebudayaan sebagai hiburan yang dahulunya hanya dipertunjukan di dalam istana sebagai hiburan pribadi bagi raja dan terkadang juga dipertunjukan kepada tamu-tamu kerajaan. Bentuk tari Melemang ini dapat dilihat dari wujudnya. Bentuk tari ini mencakup seluruh aspek yang dapat ditangkap oleh panca indra, seperti gerak, musik, dan kostum. Keseluruhan bentuk gerak dapat dilihat dari reportoar tari yang dilakukan dengan ciri khas yang unik dari tari ini adalah gerak melemang, yaitu gerakan mengambil sapu tangan yang dilakukan sambil kayang. Pengambilan sapu tangan tersebut dilakukan dengan mulut, lalu penari berdiri lagi tanpa dibantu oleh kedua tangan. Tari Melemang memiliki bobot atau isian berupa pesan yang dapat disampaikan kepada penonton, sedangkan penampilan tari Melemang dapat disampaikan secara utuh berupa penggabungan dari wujud dan isi.

Tari Melemang merupakan kesenian tradisional yang menjadi milik masyarakat di Kepulauan Riau. Namun kondisi tari Melemang boleh dikatakan diambang kepunahan karena kurangnya minat generasi muda daerah setempat untuk mempelajari tari ini. Untuk mempertahankan keberadaan tari Melemang ini dibutuhkan kerjasama dan perhatian dari berbagai pihak agar memotivasi dan mengorganisir kaum muda untuk kembali mempertahankan bentuk pertunjukan ini dan dapat mewariskan tari Melemang kepada generasi berikutnya. Oleh karena dunia saat ini terlihat semakin menyatu dengan berbagai kebudayaan dunia dengan segenap unsurnya yang menimbulkan ketergantungan antara satu dengan yang lainnya, muncul dampak berupa tarik menarik dua arus kekuatan, yaitu arus global dan lokal, arus moderenitas dan tradisi, arus lama dan baru, arus masa kini dan masa lampau, arus yang berasal dari luar dan yang bersumber dari akar setempat, yang mengakibatkan ancaman bagi perkembangan budaya atau seni lokal secara umum. Kondisi tersebut menyebabkan tari Melemang mulai tergeser.

Terjadinya perubahan tidak dapat dielakkan dalam perkembangan bentuk kesenian. Supaya proses dari kerja revitalisasi tercapai perlu dilakukan langkah-langkah sebagai berikut. Pertama, menerapkan teknik-teknik revitalisasi. Kedua, memiliki dasar untuk menghidupkan kembali tari 
tradisi. Ketiga, peneliti melakukan penelitian berdasarkan revitalisasi penari yang sudah tua dan tidak ingat lagi semua gerakan tari tradisi. Keempat, menjaga dan merawat spesifikasi tari tradisi daerah setempat, agar bentuk dan nilai tradisi tidak punah.

\section{Kepustakaan}

Alma M. Hawkins. 2003. Mencipta Lewat Tari, Terjemahan Y. Sumandiyo Hadi, Yogyakarta: Manthili.

Daryusti. 2001. Budaya Pegangan Penghulu dalam Perspektif, Yogyakarta: Penerbit Buku Pustaka

Daryusti. 2006. Hegemoni Penghulu Dalam Perpektif Budaya, Yogyakarta, Penerbit Pustaka.

Departemen Pendidikan dan Kebudayaan. Kamus Besar Bahasa Indonesia, Balai Pustaka, Jakarta, 1999.

Elfelt, Lois. 1978. A primer For Choreografer, terjemahan Sal Murgianto, Pedoman dasar penata tari. Lembaga pendidikan kesenian Jakarta.

Esten, Mursal. 1993. Minang Kabau Tradisi dan
Perubahan. Padang.

Esten, Mursal. 1999. Desentralisasi Kebudayaan. Bandung: Aksara.

Piliang. Yasraf Amir. 2004. Dunia yang Dilipat Tamasya Melampaui Batas-Batas Kebudayaan, dalam makalah Daryusti. 2006. "Keberlangsungan Tari Tradisi", WSDF STSI Padang-Panjang.

Senen, I Wayan. 1983. Pengantar Musik Tari, Yogyakarta; Akademi Seni Tari Indonesia.

Smith, Jacqueline. 1976. Dance Composition, A Practical Guide For Teacher. Diterjemahkan oleh Ben Soeharto, 1985. Komposisi Tari Sebuah Petunjuk Praktis Bagi Guru, Yogyakarta: IKALASTI.

Soedarson. 1977. Pengantar Pengetahuan dan Komposisi Tari, Akademi Seni Tari Indonesia Yogyakarta.

Tjetjep Rohendi Rohidi. 2000. Kesenian dalam Pendekatan Kebudayaan, STSSI Press. Bandung.

Umar Kayam. 1987. Seni Tradisi Masyarakat. Jakarta: Sinar Harapan

Zefri, Haliz. 2016. Tari Melemang Bintan Penaga, Bandung: Penerbit UPI Bandung. 